\title{
堆積物コアの炭素同位体比, $\mathrm{C} / \mathrm{N}$ 比および $\mathrm{FeS}_{2}$ 含有量 からみた名古屋港周辺の古気候, 古海水準変動
}

\author{
中井 信之 ${ }^{2)} \cdot$ 太田 友子 $\left.{ }^{2}\right) \cdot$ 藤澤 寛 ${ }^{2} \cdot$ 吉田 正夫 $^{3)}$
}

\section{Paleoclimatic and Sea-Level Changes deduced from Organic Carbon Isotope Ratios, $\mathrm{C} / \mathrm{N}$ Ratios and Pyrite Contents of Cored Sediments from Nagoya Harbor, Japan ${ }^{1)}$}

\author{
Nobuyuki NAKai' ${ }^{2)}$, Tomoko OHTA ${ }^{2)}$, Hiroshi FujISAWA $^{2)}$ and Masao YoshidA ${ }^{3)}$
}

Three embayment-sediment cores were taken from the bottom of west Nagoya harbor situated in Ise Bay on the coast of the Pacific Ocean, Central Japan. Three cored columns (B2, B3 and B18) obtained in lengths of 43.4, 52.5 and $51.5 \mathrm{~m}$ were dated by ${ }^{14} \mathrm{C}$-method to be 9,000 and 9,400 and 9,500 years B.P. at the deepest horizon, respectively. To study the environmental changes such as the climatic and sea-level fluctuation in the past geologic time, cored sediment samples were sampled approximately at intervals of $1 \mathrm{~m}$ along each column and analyzed for the stable carbon isotopic composition $\left({ }^{13} \mathrm{C} /{ }^{12} \mathrm{C}\right)$ and $\mathrm{C} / \mathrm{N}$ ratio of sedimentary organic materials and pyrite $\left(\mathrm{FeS}_{2}\right)$ contents.

Total organic materials in cores have a $\delta{ }^{13} \mathrm{G}$-range from -22.1 to $-27.1 \%$ relative to PDB-standard and a $\mathrm{C} / \mathrm{N}$ ratio-range from 10 to 40 in the weight ratio, and sediments have a pyrite contents-range from 0.0 to $9.0 \mathrm{mg}$ of $\mathrm{S} / \mathrm{g}$. Large ranges of $\delta{ }^{13} \mathrm{C}$ values and $\mathrm{C} / \mathrm{N}$ ratios are due to the past depositional history affected primarily by the relative contribution of terrestrial- and marine-derived organic materials to the bottom sediments. Besides a difference in the source of organic materials, $\delta^{13} \mathrm{C}$ value is affected by the sedimentary environment, temperature conditions. The large range for pyrite contents of sediments is due to a change of the source $\mathrm{SO}_{4}^{=}$concentration because authigenic pyrite is produced mainly by a bacterial reduction of $\mathrm{SO}_{4}=$ to sulfide.

From a difference in source organic materials due to the depositional environments and the temperature dependence of kinetic isotope effects in the production process of organic materials by the photosynthesis, one can expect the tendency towards larger $\delta^{13} \mathrm{G}$ values and smaller $\mathrm{C} / \mathrm{N}$ ratios (large contribution of marine planktons) of organic materials deposited during warmer and higher sea-level periods. On the contrary, small $\delta^{13} \mathrm{C}$ values and larger $\mathrm{C} / \mathrm{N}$ ratios (large contribution of non-marine planktons and terrestrial plants) can be expected in the sediments deposited during colder and lower sea-level periods, glacial ages. Pyrite contents of sediments must be higher for warmer and higher sea-level depositional conditions, because sea water contains 1,000 times of $\mathrm{SO}_{4}^{=}$in concentration as high as that of fresh water.

Based on the above-mentioned principles which have been verified by studying the present bottom surface sediments from a river and Ise Bay near Nagoya harbor, ver-

1) 1982 年 2 月 26 日受付.

2) 名古屋大学理学部地球科学教室. Department of Earth Sciences, Faculty of Science, Nagoya University.

3) 名古屋大学農学部農芸化学教室. Department of Agricaltural Chemistry, Faculty of Agricalture, Nagoya University. 
tical profiles of $\delta^{13} \mathrm{C}$ values, $\mathrm{C} / \mathrm{N}$ ratios and pyrite contents of sediment columns have been examined. Fluctuations of $\delta^{13} \mathrm{C}, \mathrm{C} / \mathrm{N}$ and $\mathrm{FeS}_{2}$ versus depth and the ${ }^{14} \mathrm{C}$-age showed the completely same climatic and sea-level change patterns for three cored columns, and as expected an inverse correlation can be found between $\delta^{13} \mathrm{C}$ and $\mathrm{C} / \mathrm{N}$.

From the fluctuation pattern of $\delta^{13} \mathrm{C}, \mathrm{C} / \mathrm{N}$ and $\mathrm{FeS}_{2}$, we can find the following feature indicating the sea-level and the climatic (temperature) changes during the end of the last glacial age (Wurm or Winsconsin) and the Holocene. A low sea-level and a cold climate can apparently be seen at the deepest horizon of sediment columns in the ${ }^{14} \mathrm{C}$ age of 8,800 to 9,000 years B.P.. After this period, the sea-level gradually rose, and the highest sea-level and climatic optimum appeared in the ${ }^{14} \mathrm{C}$-age of 6,000 to 6,700 years B.P. corresponding to "the Marine Transgression of Jomon Age". This warm and high sea-level period is followed by a low sea-level and a cold climate corresponding to a small scale "Marine Regression of Yayoi Age", a little ice age. After the little ice age, 1,000 to 1,500 years B.P., the sea-level gradually rose again toward the present. The comparison between the profiles for environmental changes by isotopic and geochemical studies and the fossil-diatom studies gave a close agreement to each other. The isotopic and the chemical records of embayment sediments can be used as useful indicators for the past environment, providing the continuous informations even for non-fossil horizons.

\section{I. は じめに}

地質時代を通じての地球表面近くの環境変化を追跡す ることを目的として，海底及び湖底堆積物に残された過 去の記録を読みとる手法が広くとり入れられている。そ の中でる，貝化石や微化石の種を同定する方法や，花粉 分析, 粒度分析による方法等が有力な武器として用いら れてきた。これに対し，1950 年代以降，安定同位体比の 測定技術の進歩にともない貝化石や有孔虫の殻の酸素同 位体比 $\left({ }^{18} \mathrm{O} /{ }^{16} \mathrm{O}\right)$ による paleotemperature や paleosalinity の推算等，同位体地球化学的方法が新しく誕生 した.

同位体的方法により EmILIANI（1966）らは第四紀後 半の古海水温変動の 全貌を解明した. この貝化石など $\mathrm{CaCO}_{3}$ 殸の ${ }^{18} \mathrm{O} /{ }^{16} \mathrm{O}$ 比を用いる方法は海洋性のものの 又儿適用され，古海水温や古海水塩分濃度の变動を明ら かにするるのである。しかし，この方法で対象とする深 海底堆積物では, 堆積速度の逮い事と, 海洋の広大さを 考光ると気候変動 (特に気温) を詳細から忠実に記録し ているとは限らない。そこで, 比較的堆積速度の速い, また水量の少ない対象として湖底堆積物の炭素同位体比 $\left({ }^{13} \mathrm{C} /{ }^{12} \mathrm{C}\right)$ を測定し古気候の推定が試みられた（NAKAI, 1972 ; Stuiver, 1975 ; Nakai and Shirai, 1978).

更に, NAKAI and YATSUmimi (1980) は古気候の変 動之密接な関係をるつ海水準変動にともない環 境が marine, non-marine と変化したと考兄られる汽水湖盆 堆積物中の有機物の炭素同位体比 $\left({ }^{13} \mathrm{C} /{ }^{12} \mathrm{C}\right)$ 変動から古
気候だけでなく古海水準の変動を詳細に㨔むことができ る事を明らかにした。

今回は, 名古屋港西部地域で得られた多数のボーリン グコアのららボーリング $\mathrm{B} 2 ， \mathrm{~B} 3$ 和よび B18 コアを用 いて沿海沖積堆積物による名古屋港周辺の古環境（古気 候，古海水準）变動を追究した結果を報告する。これら ボーリングュア中の有機物の安定炭素同位体比，有機物 の $\mathrm{C} / \mathrm{N}$ 比揖よび黄鉄鉱 (pyrite, $\mathrm{FeS}_{2}$ ) 含有量の垂直 変化を検討するとともに名古屋港周辺の河底, 海底の表 層堆積物の分析を拉こなった。

\section{II. 分 析 法}

B2，B3，B18 コアそれぞれそついて約 $1 \mathrm{~m}$ 間隔で試 料を採集し，各試料について次の分析を抏こなった.

\section{(1)有機物炭素の同位体比}

堆積物試料を $\mathrm{HCl}$ 処理により炭酸塩態の炭素を除去 し, 水洗, 風乾したのち, 酸素ガス中で温度 $950^{\circ} \mathrm{C}$ で 然痓し，更に $\mathrm{CuO}$ 炉 $\left(700^{\circ} \mathrm{C}\right)$ を通して完全に $\mathrm{CO}_{2}$ 之 寸る.次に $\mathrm{CO}_{2}$ 中の不純ガス $\left(\mathrm{H}_{2} \mathrm{O}, \mathrm{SO}_{2}\right)$ を-pentane の融点で分別蒸溜により除去した。このように精製した $\mathrm{CO}_{2}$ を Varian MAT 社製 $\mathrm{CH}-7$ 質量分析計を用い ${ }^{13} \mathrm{C} /{ }^{12} \mathrm{C}$ 比を測定し，その同位体組成は下式の上うに, PDB-standard $\left({ }^{13} \mathrm{C} /{ }^{12} \mathrm{C}=0.0112372\right.$, Craig, 1957) か らの千分偏差である $\delta^{13} \mathrm{C}(\%)$ で表現した。

$$
\begin{aligned}
& \delta^{13} \mathrm{C}(\%)=\frac{\left({ }^{13} \mathrm{C} /{ }^{12} \mathrm{C}\right) \text { sample }-\left({ }^{13} \mathrm{C} /{ }^{12} \mathrm{C}\right) \text { standard }}{\left({ }^{13} \mathrm{C} /{ }^{12} \mathrm{C}\right) \text { standard }} \\
& \quad \times 1,000
\end{aligned}
$$


(2)有機物の $\mathrm{C} / \mathrm{N}$ 比

堆積物試料を $\mathrm{HCl}$ 処理し, 水洗, 乾燥したのち, $\mathrm{Co}_{2} \mathrm{O}_{3}$ を助然剤として $\mathrm{CN}$ ーコーダにより org・ $\mathrm{C}$ 特よ び org・N を定量し， $\mathrm{C} / \mathrm{N}$ 比を求めた。

(3) $\mathrm{FeS}_{2}$

堆積物試料を水洗, 乾燥したのち, Lunge 法にしたが い, 混酸 $\left(\mathrm{HCl}: \mathrm{HNO}_{3}=1: 3\right)$ で 2 回処理して $\mathrm{SO}_{4}^{=} に$ 酸化する。その $\mathrm{SO}_{4}^{=}$を常法により， $\mathrm{BaSO}_{4}$ として重量 分析により定量し $\mathrm{FeS}_{2}$ 含有量を求めた。

以上の同位体及び化学分析の汪かに, ${ }^{14} \mathrm{C}$ 法による年代 测定を和こなった。すなわち, 堆積物試料約 $150 \mathrm{~g}$ (wet)

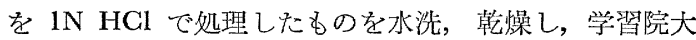
学年代測定室に测定を依頼した。

\section{III. 結果と考察}

ボーリングコアの長さとその最深部の ${ }^{14} \mathrm{G}$ 年代は次の 如くである.

$$
\text { ユア } \mathrm{B} 2 \cdots \cdots 43.4 \mathrm{~m} \quad 9,000 \mathrm{y} . \mathrm{B} . \mathrm{P} \text {. }
$$

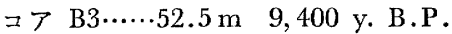

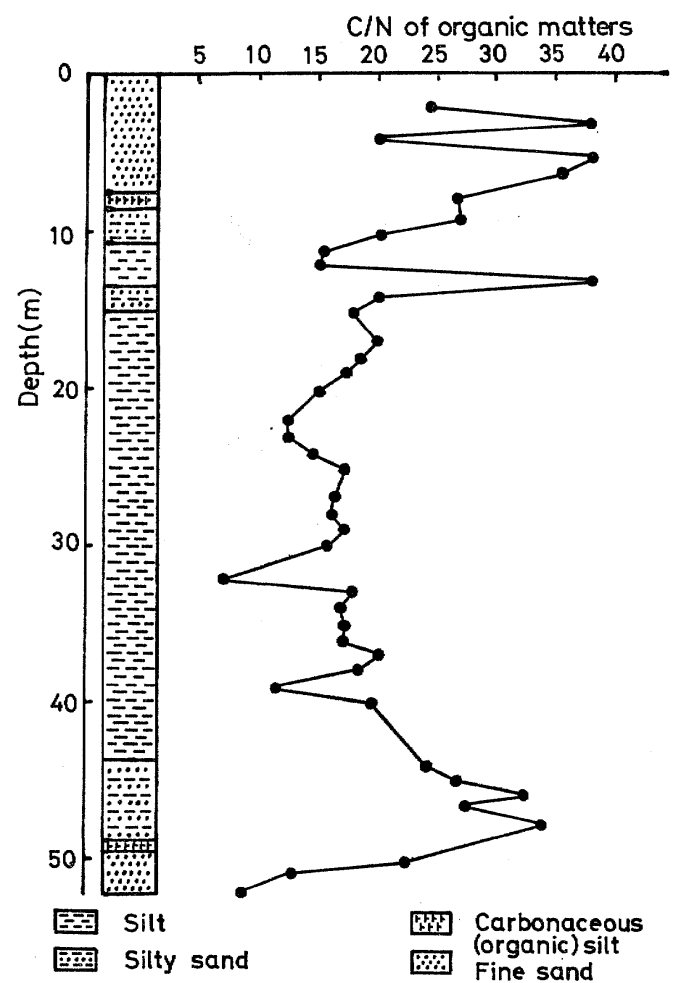

Fig. $1 \mathrm{C} / \mathrm{N}$ of organic matters and lithostratigraphy for bottom sediments from NAGOYA harbor (Gore No. 3).

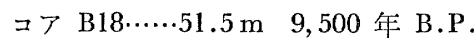

これらボーリングコアの地質柱状図から，下部砂層（ま たは熱田層)，中部泥層 (MM)，上部砂層 (US)，上部 泥層 (UM)，火分けられる(藤井・井関，1980)。Fig. 1 に B3 の地質柱状図を示した. B3, B18 では上部泥層 が欠けている。これらのコアでは下部砂層は 40〜 $45 \mathrm{~m}$ 以深にあらわれ，中部泥層（南陽層）との境界の年代は B2 で 8,840土370，B3 で 9, 250土250，B18 で 8,680土 360 y. B.P. を得た。 また中部泥層の上限は B3 で

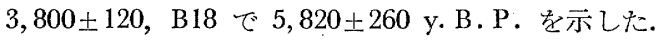

以下，これら試料について同位体地球化学的，地球化 学的観点から古環境の变遷を解析してみることにする。

有機物の岩素同位体組成 $\left(\boldsymbol{\delta}^{13} \mathbf{C}\right)$ からみた環境変化

堆積物中に含まれる有機物の $\delta^{13} \mathrm{C}$ 值は各ボーリング コアとも，垂直的に大きく変動する，その変動の様子は Fig. 2，3 怙よび4にみられるように B2 で -22.1〜 $-25,9 \%$, B3 で $-22.7 \sim-26,0 \%$, B18 で $-22.2 \sim$ $-27.1 \%$ である.これらの $\delta^{13} \mathrm{C}$ 值の变動の原因として 大きく次の 2 点があげられる。すなわち,

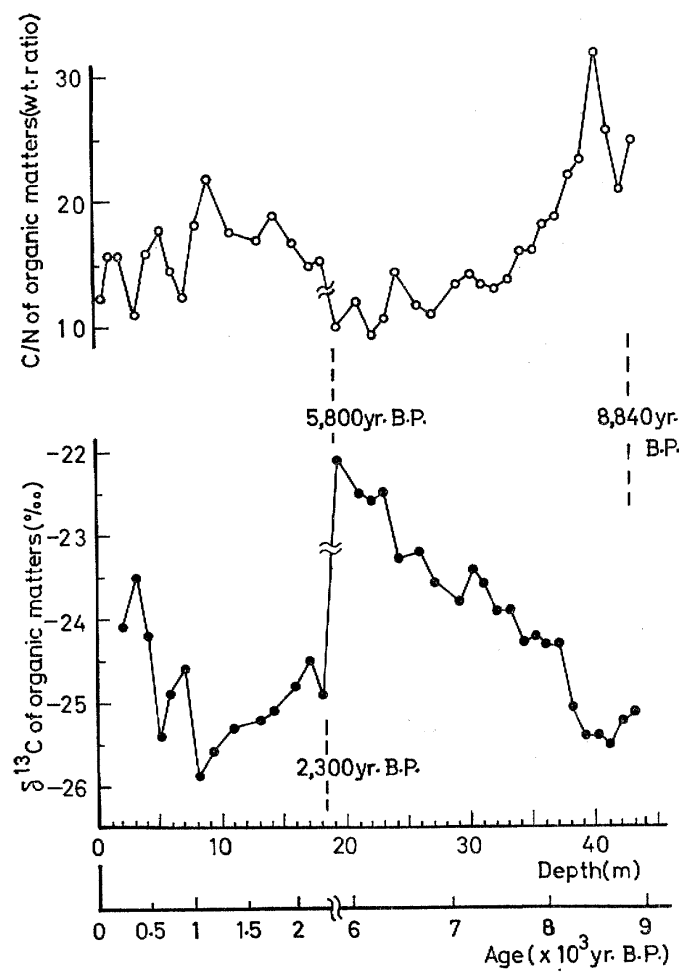

Fig. 2 Vertical ${ }^{7}$ variation in $\delta{ }^{13} \mathrm{C}$ values and $\mathrm{C} / \mathrm{N}$ ratios of organic matters in bottom sediments from NAGOYA harbor (Core No. 2). 


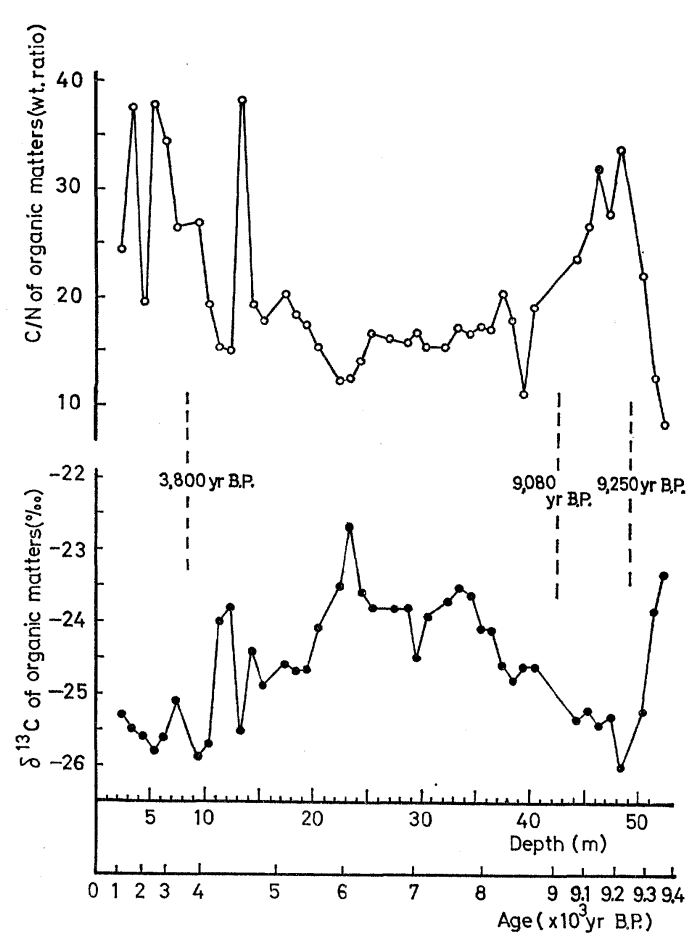

Fig. 3 Vertical variation in $\delta{ }^{13} \mathrm{C}_{\mathbf{3}}^{\mathbf{z}}$ values and $\mathrm{C} / \mathrm{N}$ ratios of organic matters in bottom sediments from NAGOYA harbor (Core No. 3).

（a）海水準変動にともなら有機物の供給源の相違

（b）気候（気温, 水温）の变動による光合成有機物 生産速度の変化

まず（a）について考えると，有機物の供給源は，主 として海洋プランクトン，陸水プランクトン及び陸上植 物の遺骸である. Fig. 5 に天然に特ける生物の $\delta^{13} \mathrm{C}$ 值の分布を示したが，それぞれの生物に関して，海洋の $\delta^{13} \mathrm{C}$ 值は淡水扣よび陸性のそれに比べて大きな值を示 し重い炭素 ${ }^{13} \mathrm{C}$ そ濃縮していることが判る. そして, 結 果的に海や湖，河の堆積物をみると下記の值をとる.

海洋堆積物………-20〜-24\%

淡水堆積物………26 - $30 \%$

このよらに両者で画然とした差異がみとめられる. 名古 屋港のように沿岸地域では, 高海水準の時期にはより多 くの海洋性生産物が堆積し, 氷河期の低海水準期には相 対的に，より多くの陸上より運ばれてきた陸性及び淡水 性生産物が堆積することになる. そして両者の中間的汽 水環境では, 両者の奇与が考觉られる.すなわら, 気候 変動にともなら海水隻変動により堆積物中にとりこまれ る有機物の供給源が変化し，そのため $\delta^{13} \mathrm{C}$ 值が変動す

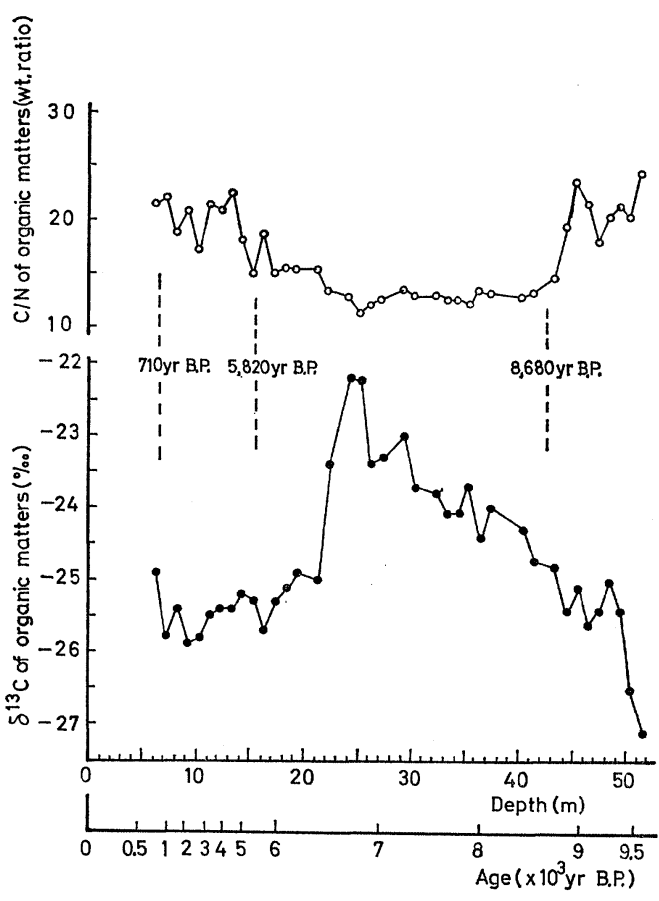

Fig. 4 Vertical variation in $\delta{ }^{13} \mathrm{C}$ values and $\mathrm{C} / \mathrm{N}$ ratios of organic matters in bottom sediments from NAGOYA harbor (Core No. 18).

ることになる。

このことを確認するために名古屋港近辺の河川（庄内 川）と伊勢湾の表泥及び境川と三河湾の表泥について有 機物の $\delta^{13} \mathrm{C}$ 值の分布をしらべた結果を Fig. 6 に示し た.この図から明らかなように， $\delta^{13} \mathrm{C}$ 值は河川から海に 入り一方的に ${ }^{13} \mathrm{C}$-rich な值をとり伊勢湾中央部及び三 河湾中央部に至って典型的な海洋生物または海洋堆積有 機物の值 -21.1 〜 - 21.6\% の值をとるよらになる.こ のように海洋性有機物と陸上なたは淡水性生物の寄与の 相異により $\delta^{13} \mathrm{C}$ が変化することが確められた. このこ とに関しては同様の結果を SACKETT (1964)，NEWMAN et al. (1973) はメキシュ湾の堆積物を用いてミシシッピ 川よりの陸性有機物の寄与の割合と $\delta^{13} \mathrm{C}$ 值の関連性を 報告している.

次に（b）について考光ると, 海洋, 淡水, 陸上の寸 ベての生物に関して，それぞれ光合成過程で温度により ${ }^{12} \mathrm{CO}_{2}$ と ${ }^{13} \mathrm{CO}_{2}$ をとり入れる速度の比 $\mathrm{k}_{1} / \mathrm{k}_{2}$ が変化 する ( $\mathrm{k}_{1}, \mathrm{k}_{2}$ はそれぞれの反応速度定数). PARK and Epstein (1960), Degens (1968), SAckett et al. (1965), NAKAI (1972) らによると，高温である程 $\mathrm{k}_{1} / \mathrm{k}_{2}$ 比は小 さく比較的 ${ }^{13} \mathrm{C}$ が多く光合成でとり入れられ $\delta^{13} \mathrm{C}$ 值が 


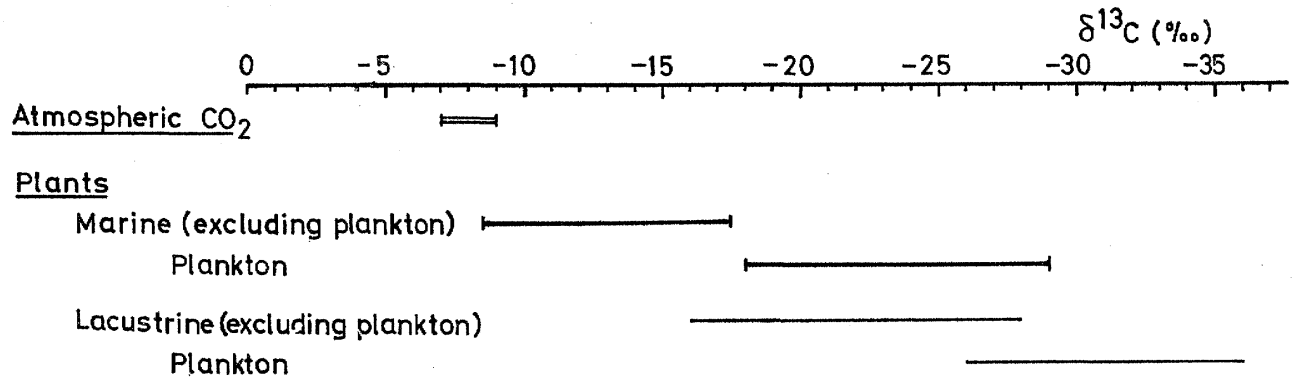

Animals

Marine

Lake and river

Organic matters in bottom sediments

Marine

Pelagic only

Lake and river

Fresh water only

Fig. 5 Distribution of $\delta{ }^{13} \mathrm{C}$ values in nature.

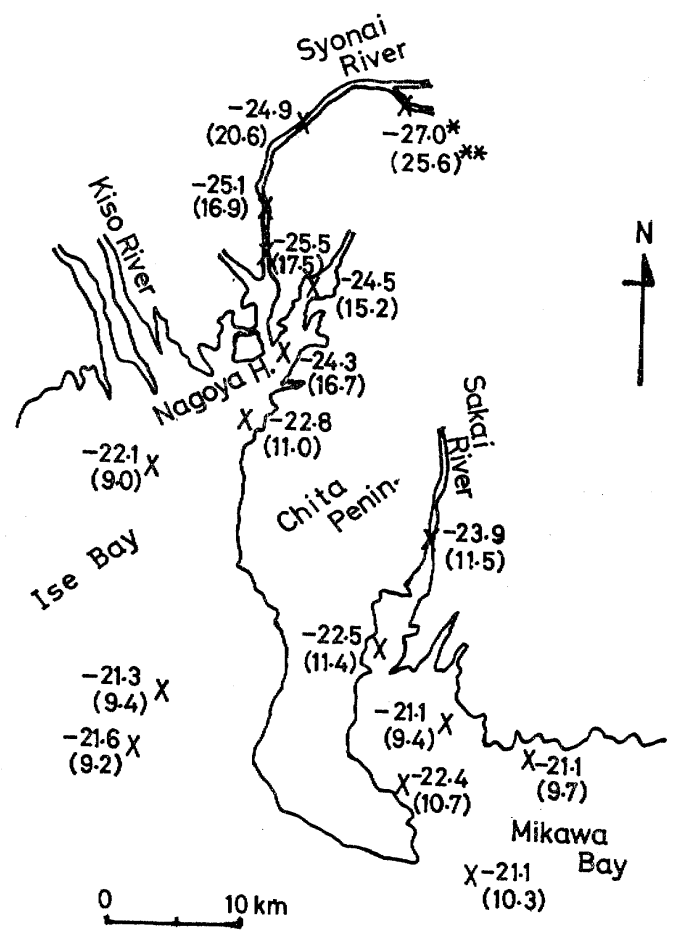

Fig. 6 Ditribution of $\delta{ }^{13} \mathrm{C}$ values and $\mathrm{C} / \mathrm{N}$ ratios of organic matters in marine and river bottom surface sediments near NAGOYA (*: $\delta^{13} \mathrm{C} \%$, ** $: \mathrm{C} / \mathrm{N}$ ratio).
大きい ${ }^{13} \mathrm{C}$ に富んだ有機物が生産されるとしている。

以上のようにして，(a)，(b) 両原因とも温暖な高海 水準期に ${ }^{13} \mathrm{C}$-rich な有機物が堆積する事になり，低温 の低海水準期には ${ }^{13} \mathrm{C}$-poor な有機物が堆積することに なる.この（a)，(b) 両原因の相乗効果により，気候及 び海水準変動は敏感に $\delta^{13} \mathrm{C}$ 值に反映する事が期待でき 万.

そこで, 再び Fig. 2，3，4 の各ボーリングコアにつ いて $\delta^{13} \mathrm{C}$ の変動を酐兆めてみる。これら図の中に示した 年代值は実測 ${ }^{14} \mathrm{C}$ 年代を示して括り, 図の横軸の年代ス ケールは実測年代值間は堆積速度一定として計算したも のである. B2 (Fig. 2)，B3 (Fig. 3)，B18 (Fig. 4) コアともに $\delta^{13} \mathrm{G}$ 值は同じ変動パターンを示す. 3 本の ボーリングコアについて共通して言えることは次の如く である。

i ) $8,800 \sim 9,000$ y. B.P. 以降，すなおち中部泥層 の基底部近くより上部に向って $\delta^{13} \mathrm{C}$ 值は上昇の一途を たどる.この事は明らかに温度の上昇と海水準の上昇を 示している.

ii ) $6,000 \sim 6,700 \mathrm{y} . \mathrm{B} . \mathrm{P}$. に $\delta^{13} \mathrm{G}$ 值の最大值が明 白にみられる。これは最高海水準期を示し，縄文海進盛 期すなわち climatic optimum に相当するものである.

iii) 縄文海進の最高海水準期の後， $\delta^{13} \mathrm{G}$ 值は再び減 少し低海水準で淡水的な環境が出現する．これは恐らく 縄文末期又は弥生時代の小海退期を示しているのである 
5.

iv）上部泥層 (UM) は B2 コアのみにみられるが， この泥層（約 1,000 y. B.P. 以降）では上部に向って $\delta^{13} \mathrm{C}$ 值は増加し, 再び海水準の上昇がみられ, 現在の 温暖期にいたっていることがわかる (Fig. 2).

v）最下部の下部砂層では $\mathrm{B} 2 ， \mathrm{~B} 3$ コアでみると，明 らかとやや海水準の上昇期がみとめられる.

vi）最高海水準期以降， $\delta^{13} \mathrm{C}$ 值は急激汇減少するよ ら飞み觉る。しかし，Fig. 2 の $\mathrm{B} 2$ コアの ${ }^{14} \mathrm{C}$ 年代実 測値をみると $19.15 \mathrm{~m}$ で，5,800 y. B.P., $18.65 \mathrm{~m}$ で 2,300 y. B.P. で此の間潐積物の不連続があることが わかる。

以上の如く，採集されたコアについては $\delta^{13} \mathrm{C}$ 值の変 化から連続的な気候変化と海水準の動きを知ることがで きた。

この $\delta^{13} \mathrm{C}$ 值の変動により推定した海水準の動きによ る海洋環境と淡水性（河性）環境の変化を森（1980）飞 よる同一コア (B2) の珪藻分析の 結果と対比したのが Fig. 7 である. 珪藻分析の結果, 淡水種の\%の高い時 期は明らかに $\delta^{13} \mathrm{C}$ 値は低く淡水的環境を示している. また海洋種（Melosira sulcata，Cyclotella striata 等)の 多い時期の $\delta^{13} \mathrm{G}$ 值は大きく ${ }^{13} \mathrm{C}$ 飞富んでいる事がわか
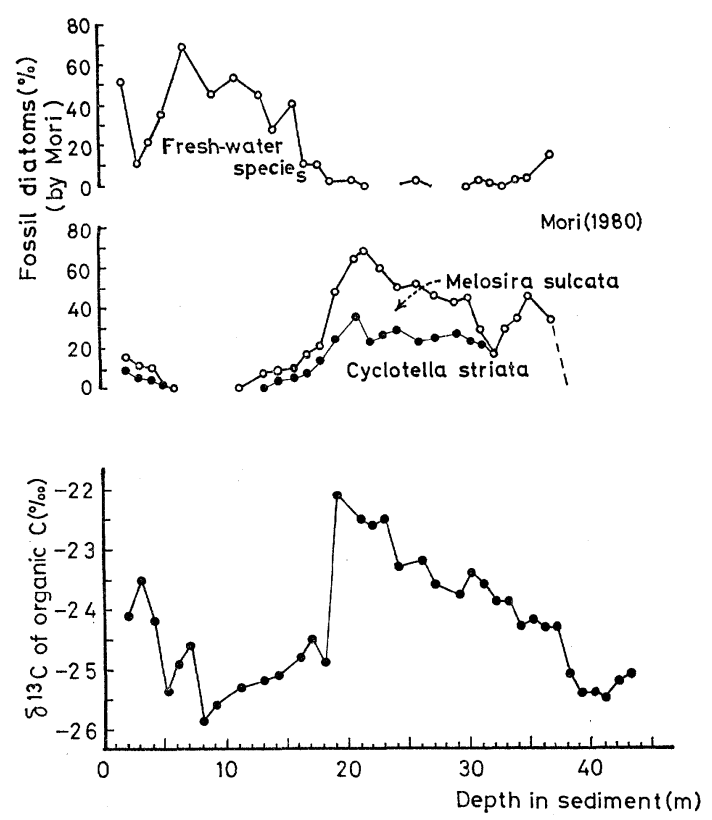

Fig. 7 Vertical variation of fossil diatom species and $\delta{ }^{13} \mathrm{C}$ values (organic) in bottom sediments from NAGOYA harbor (Core No. 2).
る. このように珪藻分析と $\delta^{13} \mathrm{C}$ 値の变動パターンは非 常によく一致している.

\section{$\mathbf{C} / \mathbf{N}$ 比からみた環境変動}

前述のよらに，堆積物中の有機物の供給源は大きく分 けて海洋性と陸性がある。海洋性の有機物は主として動 植物プランクトンであり，陸性のもの淡淡水動植物プラ ンクトンと陸上植物である. これらのらちプランクトン の $\mathrm{C} / \mathrm{N}$ 比（重量比）は約 6〜7 であるのに対して陸上 植物では cellulose や lignin の上うと炭素に富んだ有 機物が主体を占めて特り，その $\mathrm{C} / \mathrm{N}$ 比は 30〜40 以上 の値をるっている.

まず，名古屋周辺の河川及び海の表泥の有機物につい て $\mathrm{C} / \mathrm{N}$ 比を求めた結果を Fig. 6 に示した. 庄内川の 上流部では $\mathrm{C} / \mathrm{N}$ 比は 25.6 で明らかに陸上植物の寄与 の大きい事を示して赫り，海に近づくに従って一方的に 小さくなり，伊勢湾沿岸から湾中央に向って全く一方的 に小さい値をとり，湾央では 9.2〜9.4 となる. 三河湾 についても全く同様の傾向を示し，この事は明らかに陸 性有機物の寄与が海洋的環境になる程少なくなりプラン クトンのみの $\mathrm{C} / \mathrm{N}$ 比飞近ずく事を明らかに示してい ๖.

ボーリングュアについても同様に $\mathrm{C} / \mathrm{N}$ 比の垂直変動 から海洋, 汽水, 淡水環境の変動, なわち海水準と気候 変動を明らかにする事ができるはずである。とごで 3 本 のボーリングュアの $\mathrm{C} / \mathrm{N}$ 比の深度また恃年代による変 動パターンを Fig. 2，3，4 で朓めてみる。この $\mathrm{C} / \mathrm{N}$ 比は過去 9,000 年の間に $10 \sim 40$ と大きく変動し, $\delta^{13} \mathrm{C}$ 值から縄文海進の盛期と推定した時期には $\mathrm{C} / \mathrm{N}$ 比は最 低值約 10 の海洋的な值を，海退期之推定した時期には 大きな值をとり陸性有機物の寄与の大きい事が明確であ る. そして, $\delta^{13} \mathrm{C}$ 值と $\mathrm{C} / \mathrm{N}$ 比の変動パターンは全く 逆相関を示した. このように $\mathrm{C} / \mathrm{N}$ 比もまた気候変動や 海水準変動を忠実に記録しているのである。

次に $\mathrm{C} / \mathrm{N}$ 比が海洋源の有機物と陸源の有機物（特に 陸上植物）の寄与の割合により変動するために環境のよ い指標になる事の確認を抢こなった。すなわち、コア B18 について 深度の異なる $(9.3,12.3 ， 13.3 ， 19.3$, $21.3 ， 35.3 ， 36.3 ， 40.3 ， 49.3 ， 50.3 ， 51.3 \mathrm{~m})$ 試料に ついて，腐植酸を抽出し，それらの赤外線吸収スペクト ル (Fig. 8) 及び示差吸収スペクトル (Fig. 9) をとっ た。赤外線吸収スペクトルでは $9.3 ， 12.3 ， 13.3 \mathrm{~m}$ 層 で $1,500 \mathrm{~cm}^{-1}, 1450 \mathrm{~cm}^{-1}, 1410 \mathrm{~cm}^{-1}$ 亿強い吸收がみ られ，19.3 $\mathrm{m}$ と $51.3 \mathrm{~m}$ 亿弱い吸収が認められ，lignin 的性格の強い事が推定され充。采た示差吸収スペクトル 


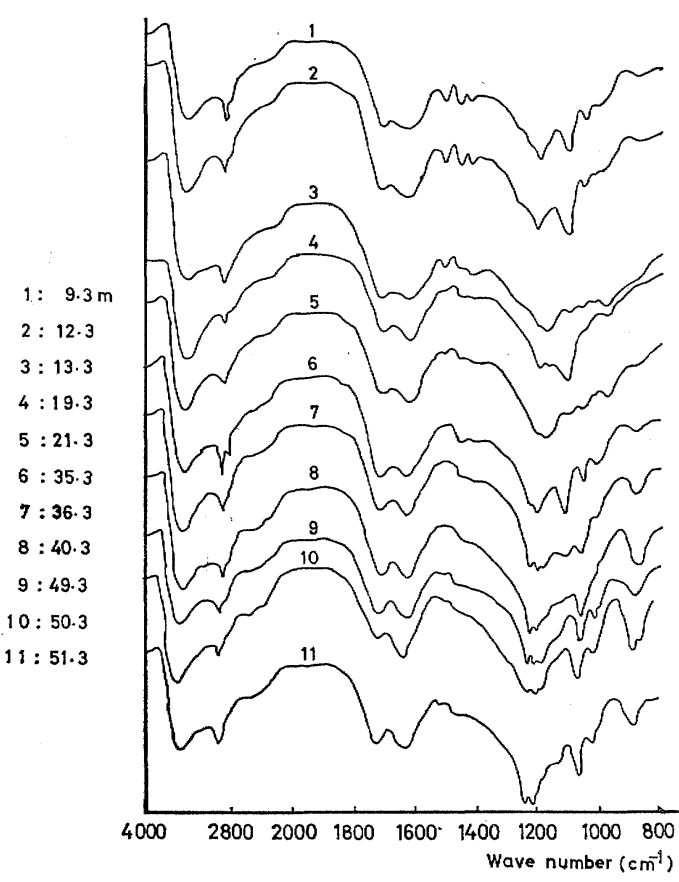

Fig. 8 IR spectra for humic acid in bottom sediments from NAGOYA harbor (Core No. 18).

では 9.3, $12.3,13.3 \mathrm{~m}$ 層で $250,300,350 \mathrm{~nm}$ に, $50.3,51.3 \mathrm{~m}$ で $250,350 \mathrm{~nm}$ に強い吸収極大が認めら れリグニン的性格の強い事が実証された. この様にし $\tau, \mathrm{C} / \mathrm{N}$ 值の高い低海水準期の堆積物には陸性植物の lignin が多い事，そして C/N 比の低い高海水準期の堆 積物には陸性植物としての lignin 的性格は認められな い事が明白になった．従って $\mathrm{C} / \mathrm{N}$ の変動は気候変動及 び海水準変動による有機物供給源の相異によるものであ るといえる。

$\mathrm{C} / \mathrm{N}$ 比の変動は $\delta^{13} \mathrm{G}$ 值の変動之同様に過去の環境変 遷を示すものであるが， $\mathrm{C} / \mathrm{N}$ 比と $\delta^{13} \mathrm{C}$ 值との間の関 係をみるとFig.10のようになり，きれいな逆相関があ 万。

\section{硫化物硫黄 $\left(\mathrm{FeS}_{2}\right)$ 含量からみた環境変化}

コア B3，B18 について黄鉄鉱 $\left(\mathrm{FeS}_{2}\right)$ の S としての 含有量の垂直変化を Fig. 11，12 に示した。その含有量 は $0.0 \sim 9.0 \mathrm{mg} / \mathrm{g}$ と大きく変動する.これらの $\mathrm{FeS}_{2}$ は $\mathrm{SO}_{\overline{4}}^{\overline{\overline{4}}}$ が堆積物の表層近くで硫酸還元バクテリアによ り還元され $\mathrm{H}_{2} \mathrm{~S}$ を生産し, 次の様に続成作用の過程で 作られる。

$$
\begin{aligned}
\mathrm{SO}_{4}^{\overline{4}} & \stackrel{\text { 硫酸還元 }}{\text { パクテリア }} \mathrm{H}_{2} \mathrm{~S}+\mathrm{Fe}(\mathrm{OH})_{3} \longrightarrow \\
\mathrm{FeS} \cdot \mathrm{nH}_{2} \mathrm{O} \text { (hydrotroilite) } & \longrightarrow \mathrm{FeS}_{2}
\end{aligned}
$$

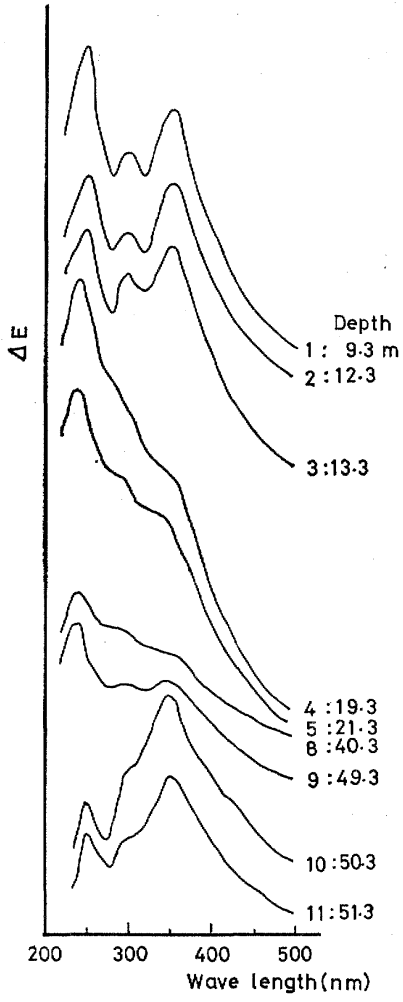

Fig. 9 Difference spectra for humic acid in bottom sediments from NAGOYA harbor (Core No. 18).

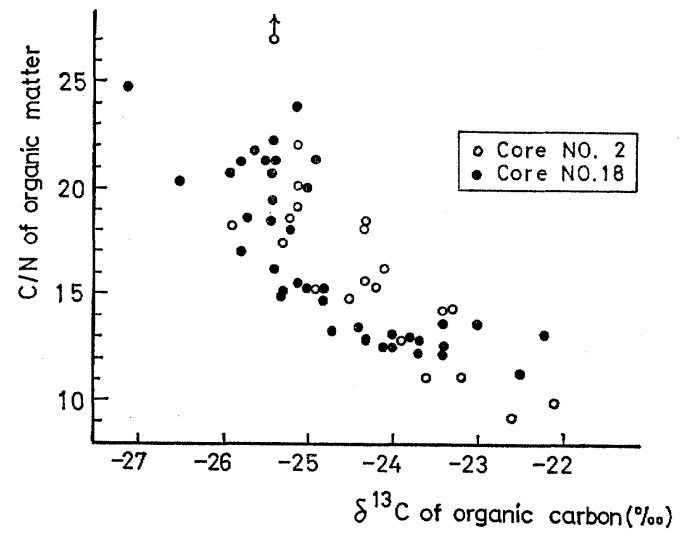

Fig. 10 Relationship between $\delta^{13} \mathrm{C}$ values and $\mathrm{G} / \mathrm{N}$ ratios of organic materials in cored sediments from NAGOYA harbor (Core Nos. 2 and 18).

このようにして生成した $\mathrm{FeS}_{2}$ は安定な鉱物で堆積物 中に保存されている.この $\mathrm{FeS}_{2}$ の堆積物中での含有量 は次の 3 点によりきまる. 


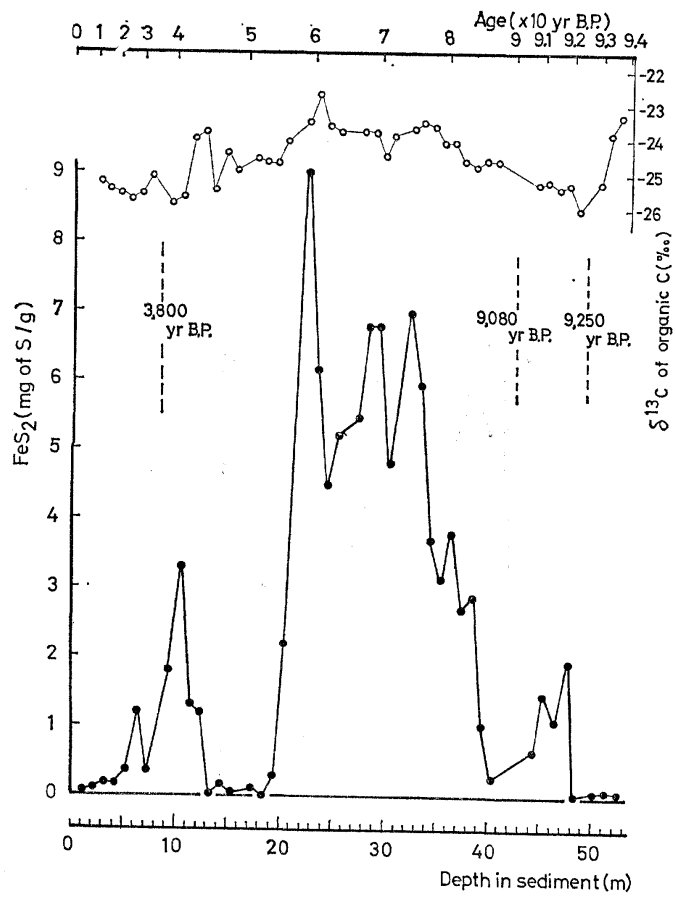

Fig. 11 Vertical variation in $\mathrm{FeS}_{2}$ (pyrite) contents and $\delta^{\mathbf{1 3}} \mathrm{G}$ (organic) values of bottom sediment from NAGOYA harbor (Core No. 3).

\section{i ) 原料物質である $\mathrm{SO}_{\overline{4}}^{=}$濃度}

ii ）酸化還元電位

iii）還元バクテリアのための有機物量

名古屋港コアの場合, これら 3 点のうら最も重要である のはｉ）である。すなわち，海水環境と淡水環境とでは $\mathrm{SO}_{\overline{4}}$ 濃度は下に示すように，桁らがいに異なり，海水 では淡水の 1,000 倍にも達するのである.

標準海水 : $2,600 \mathrm{mg} \mathrm{SO}_{4}^{\bar{m}} / 1$

淡 水: 数 $\mathrm{mg} \mathrm{SO}_{4}^{\bar{m}} / 1$

そこで, 堆積当時の $\mathrm{SO}_{4}^{=}$濃度と堆積物中の $\mathrm{FeS}_{2}$ 含 量が密接な関係にあるはずである. 従って, 堆積物が堆 積した当時の環境（海水, 汽水, 淡水) により, 香た気 候や海水準変動により， $\mathrm{FeS}_{2}$ 含量は変動することにな る. Fig. 11，12 をみると $\delta^{13} \mathrm{C}$ 値の変動とよく似た変 動パターンを示し, 9,000 y. B.P. 前後から pyrite 含 量は増加し明らかに海水準の上昇がみられ約 $6,000 \mathrm{y}$. B.P.〜6,700 y. B.P. で最高值を与光縄文海進の最盛 期を示している.それ以降は pyrite 含量は減少し縄文 末期又は弥生時代の海退期である淡水的環境が明白にあ らわれている。

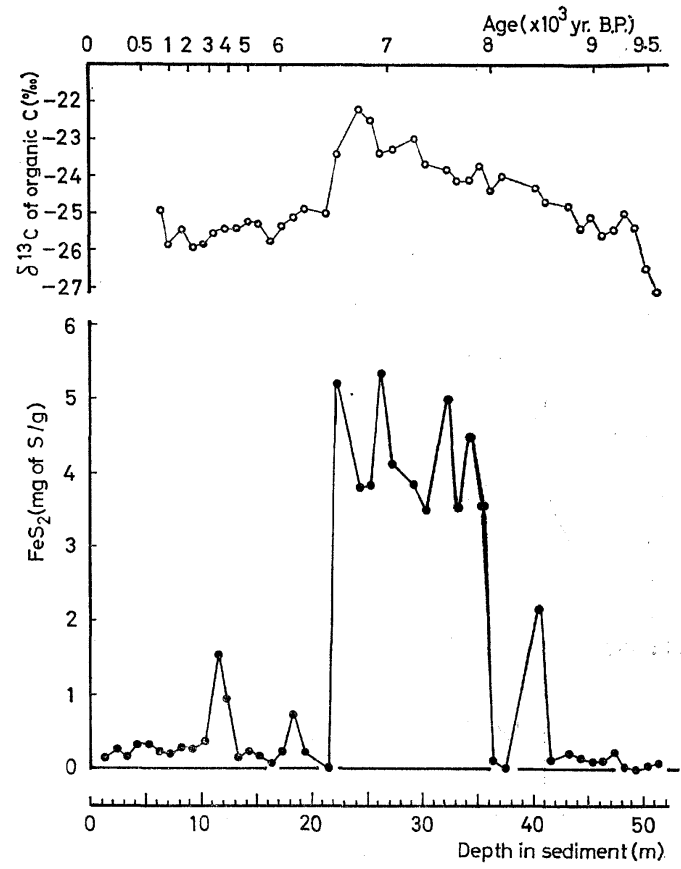

Fig. 12 Vertical variation in $\mathrm{FeS}_{2}$ (pyrite) contens and $\delta{ }^{13} \mathrm{C}$ (organic) values of bottom sediment from NAGOYA harbor (Core No. 18).

pyrite 含量の変動の詳細な解析は今回は略すが，いづ れにしても pyrite 含量も一つの環境変動の有力な指標 になるのである。

\section{IV.おわりに}

以上に述べた如く名古屋港周辺のボーリングコアを用 い沿海地域の 環境解析に堆積有機物の $\delta^{13} \mathrm{G}$ 值, $\mathrm{C} / \mathrm{N}$ 比括よび pyrite 含有量の変動を適用した. その結果, paleotemperature のように温度を数值で表わすことは できないが，詳細な気候及び海水準変動の 記録を読み とることができた。すなわち，最終水期後の海水準の 上昇の様子そして 6,000 y. B.P. 6,700 y. B.P. に climatic optimum, 縄文海進全盛期が見出され，その後 の温度の低下，海水準低下，淡水的環境の出現（縄文末 期又は弥生時代の小海退期）が明白に示された. また， この小海退期の後（約 1,000 y. B.P. 以後）再び温度 の上昇, 海水準上昇がみられ現在にいたっている.

$\delta^{13} \mathrm{C}$ 值, $\mathrm{C} / \mathrm{N}$ 比, pyrite 含量すべてからほぼ同じ 環境変動が導かれたが，今後これらの組合せによって， より詳細な解析を進め，更に全濃尾平野にわたって異な る位置のボーリングュアの結果を対比することにより定 
量的な海水準艺の他の環境変動を明らかにしてらく予定 である。

\section{引用交 献}

CraIG, H. (1957) Isotopic standards for carbon and oxygen and correction factors for mass spectrometric analysis of carbon dioxide. Geochim. et Cosmochim. Acta, 12, p. 133-149.

Degenss, T. (1968) Metabolic fractionation of carbon isotopes in marine plankton, Part I. Deep-Sea Res., 15, p. $1-9$.

Emiliani, C, (1966) Paleotemperature analysis of the Caribbean and a generalized temperature curve for the last 425, 000 years. Jour. Geol., 74, p. 109126.

藤井昭二・井関弘太郎 (1980) 名右屋港に夕られる完新 世の海進・交部省科学研究費補助金総合研究報告 (A)

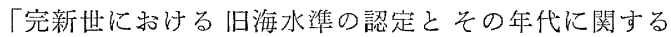
研究」, p. 27-30.

森 忍 (1980) 名古屋港試錐の 珪藻分析. 同上, p. $68-70$.

NAKaI, N. (1972) Garbon isotopic variation and the paleoclimate of sediments from Lake Biwa. Proc.
Japan Acad., 48, p. 516-521.

NAKAI, N. and ShIraI, Y. (1978) Paleoclimatic features in Central Japan based on the stable isotope compositions of Lake Biwa sediments and speleothems. Proc. Japan Acad., 54, p. 81-86.

Nakai, N. and Yatsumimi, T. (1980) Paleoclimatic variation based on carbon isotopic compositions, $\mathrm{C} / \mathrm{N}$ ratios and sulfur contents of cored sediments from brackish basins. Abstract of the SIL XXI Congress in Kyoto, p. 180.

Newman, J. W., Parker, P. L. and Behrens, E. W. (1973) Organic carbon isotope ratios in Qaternary cores from the Gulf of Mexico. Geochim. et Cosmochim. Acta, 37, p. 225-238.

PArK, R. and Epstein, S. (1960) Carbon isotope fractionation during photosynthesis. ibid. 21, p. 110126.

SACKETt, W. M. (1964) The depositional history and isotopic organic carbon composition of marine sediments. Marine Geol., 2, p. 173-185.

Sackett, W. M., Eckelman, W. R., Bender, M. L. and Allan, W. H. Be (1965) Temperature dependence of carbon isotope composition in marine plankton and sediments. Science, 148, p. 235-237. 